\section{POWER GENERATION}

\section{MHD Still Running}

A BULLTSH account of the commercial prospects for magnetohydrodynamic generation has been produced by the International MHD Liaison Group. The group was set up jointly by the European Nuclear Energy Agency and the International Atomic Energy Agency to arrange for the exchange of information on MHD between laboratories in member countries. The report is based on a conference held in Warsaw last year at which it appeared that MHD power generation is now at the stage of pilot installations. The first of these, an open-cycle, oil-fired plant of $25 \mathrm{MW}$ output, is under construction in the Soviet Union. It will be at least ten years, however, before MHD power stations can begin to take a share of the base load demand.

MHD is essentially an efficient means of converting heat to electricity. In the process, energy is extracted directly from an electrically conducting fluid flowing through a magnetic field. Only fossil fuel heat sources can at present provide high enough temperatures for the extraction process to be efficient, although suitable high-temperature nuclear reactors may eventually be developed. At the conference, it was estimated that the efficiency of a full-scale open-cycle plant should initially be between 48 and 50 per cent, and improvements in technology, "foreseeable, but as yet undemonstrated", could raise this to 60 per cent. This makes it an attractive competitor to conventional fossil-fired plants which have maximum efficiencies of about 40 per cent.

So why has the British Central Electricity Generating Board decided that the development of MHD plants cannot be economically justified in Britain (Nature,222, 1023; 1969) ? The chief reason is that the cost of nuclear reactors is still tending to fall while costs of fossil fuel fired plants are rising. Elsewhere, much will depend on whether the liaison group's optimism about the several technological problems is justified. One problem is the amount of low grade heat produced in the combustion chamber and duct; according to Dr L. Rotherham of the CEGB, this will reduce the efficiency of the process well below the theoretical value, and perhaps even below 50 per cent.

Another difficulty is that in most work so far on MHD natural gas has been used as a fuel because of the corrosive chemistry associated with the impurities in coal; but coal is the preferred fuel in many parts of the world because of its abundance and low cost. One solution may be to purify the coal before using it. Then the generating duct has to withstand temperatures above 2,000 $\mathrm{K}$ and supersonic flow speeds, and so far no really suitable material has been found.

\section{METRICATION}

\section{SI and the Law}

The Minister of Technology, Mr A. Wedgwood Benn, announced last week the setting up of a committec to advise on the legal problems attending the introduction of metric units in Britain. It is hoped that the switch to metric units will be mostly complete by the end of 1975, and it will be the committee's job to point out the potential legal stumbling blocks.

In principle, the British Government has embraced the SI system of units. In most instances, it hopes that the changeover will be straightforward, a natural continuation of the switch to decimal currency in 1971. But there are some basic questions to be answered before the Government can settle on the most appropriate units. For example, should new legislation embody the recommendations of the British Standards Institution in allowing the millimetre as a legal unit, or will the situation arise where the BSI recommends one unit and the Government a different one? And what will happen to units of tyre pressure or petrol consumption? What will be the fate of legislation with units in feet or pounds, for which a change to SI will mean either the creation of ridiculous fractions or else rounding off and thus effectively changing the law? One obvious example is the case of a magistrate who must live within a given number of miles from his court.

The new committee will be composed of experts from the principal government departments and research councils, as well as from the Metrication Board and the British Standards Institution. It is emphasized by the committee's chairman, Mr A. H. A. Wynn, that it is not proposed to introduce new areas of compulsory use of given units. An exception is the case of drugs, however, where compulsory units will become operative in 1971.

\section{CONSERVATION}

\section{National Parks in Australia}

MoRe national parks and nature reserves in Australia are called for in a report by the Australian Academy of Science (National Parks and Reserves in Australia, 1968). It asks that the State and Commonwealth authorities should assess the adequacy of the existing parks and reserves so as to ensure that the most important environments and habitats are permanently set aside as national parks and reserves. It reiterates its plea for an inventory of Australian flora and fauna, the subject of an earlier report by the academy's Fauna and Flora Subcommittee (see Nature, 222, 407; 1969). Such a survey, it says, would make possible a proper assessment of land needed. There is some activity in this direction already, but the academy considers this should be extended and speeded up. The eastern coastline of Australia, the arid zone of central Australia and the marine environment, particularly the Great Barrier Reef, are singled out as areas needing special consideration. Parks and reserves, the report says, need to be designated in these areas urgently.

Australian universities have recently become more interested in training students in wildlife conservation and park management, but the academy thinks they could do more. One of many fields of research in urgent need of investigation is the effect of bushfires on habitats. The frequency of intense bushfires in Australia is far greater than that in most other parts of the world-nearly 300,000 acres of national parks and State parks in New South Wales alone were burnt out in 1965 .

More national parks and reserves will stretch the already inadequate resources allocated by authorities for existing parks. The academy therefore asks that all governments in Australia should provide more 
resources for all aspects of national parks and reserves. Finally, the academy asks for greatcr participation by the Commonwealth government in conservation and suggests that a commonwealth authority be established to promote and coordinate policy on national parks.

\begin{tabular}{|c|c|c|c|c|c|c|}
\hline ATSTRAIIAN : & XATIONA & L PARKS & AN1) RESER & VVFS, $30 \mathrm{JUN}$ & NE 190 & \\
\hline State & $\begin{array}{c}\text { Popula- } \\
\text { tion } \\
1966 \\
\text { (thou- } \\
\text { sands) }\end{array}$ & $\begin{array}{c}\text { Number } \\
\text { of } \\
\text { parks } \\
\text { and } \\
\text { reserves }\end{array}$ & $\begin{array}{r}\text { Area } \\
\text { ('000 } \\
\text { acres) }\end{array}$ & $\begin{array}{c}\text { Area of } \\
\text { nat.parks } \\
\text { and } \\
\text { reserves } \\
\text { ('000 acres) }\end{array}$ & $\begin{array}{l}\% \text { of } \\
\text { State } \\
\text { area }\end{array}$ & $\begin{array}{c}\Lambda \text { cres } \\
\text { per } \\
\text { capita }\end{array}$ \\
\hline New South Wales & 4,231 & 89 & 198,037 & 2,144 & $1 \cdot 1$ & $0 \cdot 5$ \\
\hline Victoria & 3,218 & 48 & & & 0 . & $0 \cdot 2$ \\
\hline Queensland & 1,661 & 258 & 426,880 & 2,364 & $0 \cdot 6$ & $1 \cdot 4$ \\
\hline South Australia & 1,091 & 110 & 243,245 & 2,889 & $1 \cdot 2$ & $2 \cdot 6$ \\
\hline Western Australia & 836 & 380 & 624,589 & 3,042 & 0.5 & $3 \cdot 6$ \\
\hline Tasmania & 371 & 113 & 16,885 & 712 & $4 \cdot 2$ & 1.9 \\
\hline Northern Territory & 37 & 34 & 332,979 & 11,638 & $3 \cdot 5$ & 315.0 \\
\hline Australian Capital & & & & & & \\
\hline Territory & 96 & 1 & 601 & 12 & $1 \cdot 9$ & $0 \cdot 1$ \\
\hline Australia & 11,541 & 1,033 & $1,899,462$ & 23,295 & $1 \cdot 2$ & $2 \cdot 0$ \\
\hline
\end{tabular}

PESTS

\section{Beefles, Birds and Rats}

A RATHER belated but full report of the activities of the Ministry of Agriculture's Infestation Control Laboratory in the three years 1965-67 has now been published (HMSO, 14s $6 d$ ). The laboratory is responsible for research and development in the control of all sorts of pests-grain beetles, mites, pigeons, rats, rabbits, coypus and mink - not forgetting many forcign insects brought into Britain with imported commodities. The laboratory has also recently becn increasingly concerned with the safe use of toxic chemicals in agriculture. Information is being collected on the different uses of pesticides in controlling mites and inscets in foodstuffs, and analyses are continually being made of chemicals such as organophosphorus compounds, malathion and inorganic bromide in imported goods. DDT was detected in most of the 87 samples of imported grain tested in the three year period, but the amounts were usually small-only two samples contained more than 2 parts per million of DDT. Research into pesticide residues in wild birds and mammals is also carried out. Considerable residues of DDT and its metabolites were found in bodies of birds from an orchard site in Sussex. In parallel with this work, toxicity tests are carried out in the laboratory using feral pigeons, Japanese quails, house sparrows and domestic chicks. On the biochemical side, the metabolism of warfarin by rats and of DDT by pigeons has been studied and several techniques have been developed in the diagnosis of organophosphorus poisoning.

The rodent section has been spending a lot of time investigating warfarin resistance in the common rat. It reports that there seem to be three different types of resistance, each currently confined to separate areas in England and Wales-in Montgomeryshire and Shropshire, Nottinghamshire and Gloucestershire. It seems that the best solution to the resistance problem will be the development of new rodenticides that kill warfarin-resistant rats as safely and effectively as warfarin kills non-resistant animals. One of the most promising chemicals being investigated is coumatetralyl (3 (a-tetraly])-4-hydroxycoumarin), which is an anti-coagulant like warfarin. Laboratory trials suggest, however, that warfarin-resistant rats are to some extent also resistant to coumatetralyl, but the few field trials that have been possible indicate that this resistance should not be of immediate practical importance. In the long term, the laboratory believes that alternative poisons with a different mode of action from the anti-coagulants will have to be found.

\section{Parliament in Britain}

\section{Ocean Pollution}

Mr F. Mulley, for the Foreign and Commonwealth Affairs Office, said that the Intergovernmental Maritime Consultative Organization, which operates an international convention against oil pollution, is convening a conference in November to consider liability and compensation for oil pollution from ships and the need for a convention covering other forms of pollution. IMCO, he said, is the best agency for this sort of problem. The North Sea arrangement, for example, comes into effect next month and is a step in the right direction. (Oral answers, July 21.)

Intelsat

Mr Mulley said that he knows of no proposals to bring Intelsat under United Nations auspices. Although agrecing that Intelsat should be organized so that all members can participate fully in running the organization, Mr Mulley said he saw no reason to change its commercial status. It is a successful commercial enterprise, and all members of the United Nations and its agencies are free to join the existing 68 membcrs. (Oral answers, July 21.)

\section{Fluoridation}

Mr R. Crossman, Secretary of State for Social Services, gave some idea of the money that might be saved if local government began large-scale fluoridation of domestic water supplies. In Watford, after 11 years of fluoridation, he said, there has been a substantial reduction in the number of children requiring dental fillings. If these reductions are anything to go by, 21,000 fewer fillings a year would be needed in a population the size of the London borough of Brent, which would result in a saving of $£ 20,000$. (Written answer, July 21.)

\section{National Electricity Control Centre}

Mr R. Mason, Minister of Power, said that the new CEGB national control centre, equipped with British computers and costing $£ 1.8$ million, will be one of the most up to date in the world. The present centre, which was built in 1961, has been made obsolescent by the rapid growth in the electric power system. "Oral answer, July 22.)

\section{Satellites in Orbit}

Tus Minister of Technology said that on July 24, 1,750 objects, including 371 satellites, were in orbit

\begin{tabular}{|cc|}
\hline Country of origin & Number of satellites \\
USA & 291 \\
USSR & 67 \\
France & 5 \\
Britain & 2 \\
Canada & 3 \\
ESRO & 3 \\
\hline
\end{tabular}

about the Earth. At the same date, six lunar probes were in orbit about the Moon. (Written answer, July 25.) 